\title{
The EU Memorandum on lifelong learning. Old wine in new bottles?
}

\author{
Carmel Borg and Peter M ayo* \\ University of $\mathrm{M}$ alta
}

This paper provides a critical analysis of the EU 's M emorandum on lifelong learning in light of the evolution of the concepts of lifelong education and lifelong learning from the late sixties onward. It also analyses this document in light of the forces of globalisation that impinge on educational policymaking in Europe as well as the all-pervasive neo-liberal ideology. The paper moves from theory to practice to provide critical considerations concerning certain 'on the ground' projects being presented as 'best practice' in EU documents. It brings out the neo-liberal tenets that underlie much of the thinking and rationale for these projects, and indicates, in the process, how much of the old U NESC O discourse of lifelong education has been distorted to accommodate capitalism's contemporary needs. An alternative conception of lifelong learning is called for.

\section{Introduction}

In this paper, we shall focus on the EU'S M emorandum on lifelong learning (CEC, 2000) and examine its implications for educational practice in neo-liberal times. We shall reacquaint readers with the original humanist concept of 'lifelong education' promoted by U NESCO in the 1970s, as propounded by the 'F aure report' (L earning to be, 1972). T his concept was expounded by a number of scholars who had contributed to that debate, notably G elpi, D ave, Cropley, Wain, Suchodolski and Lengrand, and because of this, constant reference will be made to their writings. We shall then trace the subsequent use of this concept, albeit in its more popular contemporary garb, 'lifelong learning', and shall critically analyse 'on the ground projects', said to be inspired by the $\mathrm{M}$ emorandum, bearing in mind the larger neo-liberal scenario.

\section{The context}

In M arch 2000, the Lisbon European Council set the European U nion (henceforth $\mathrm{EU}$ ) the goal to become the "most competitive and dynamic knowledge-based society

\footnotetext{
* Corresponding author. Faculty of Education, University of Malta, Msida MSD 06, Malta. Email: p.mayo@um.edu.mt
} 
in the world', a goal which was reaffirmed, the following year, at the Stockholm European Council (CEC, 2001, p. 6). The strategy for this purpose entailed such elements as:

- the adaptation of education and training to offer tailored learning opportunities to individual citizens at all stages of their lives;

- the promotion of employability and social inclusion through investment in citizens' knowledge and competences;

- the creation of an information society for all;

- the fostering of mobility. (CEC, 2001, p. 6)

Eight months later, the European Commission issued a M emorandum on lifelong learning (CEC, 2000) on the basis of the conclusions reached during the 1996 European $Y$ ear of Lifelong Learning ${ }^{1}$ and 'subsequent experience gained at European and national levels' (CEC , 2001, p. 7). The European Commission states that the $\mathrm{M}$ emorandum formed the basis of a European wide-consultation process, 'organised as close to the citizens as possible', and:

... the M ember States, the EEA, and candidate countries each conducted their own inclusive and wide-ranging consultation involving relevant national bodies. (CEC, 2001, p. 7)

This consultation process involved debates, national M emorandum dissemination seminars, the provision of national reports regarding lifelong learning initiatives, and work towards the development of national strategies for lifelong learning. As M urphy (1997) has shown, lifelong learning has been on the EU 's agenda for quite some time (p. 362). Lifelong learning, or its earlier version, 'lifelong education', has, for many years, been part of the popular rhetoric surrounding education, with the term being banded about by governments, international organisations, educationists and politicians so that a trendy flavour is given to their views on educational matters. ${ }^{2}$

\section{Genealogy of the concept}

In a very comprehensive article, John F ield (2001) states that 'discussions of lifelong learning predated the upsurge of interest in the late 1960s and early 1970s', and he traces the idea back to the intellectual ferment that characterised the post-WWI years (p. 5). O ne of the major exponents of the lifelong education philosophy of the late 60s and 70s, Ettore Gelpi states:

$M y$ thinking is that lifelong education, fundamentally, belongs to the history of education of all countries; it is not therefore a new idea. It lies in the Chinese tradition, in Indian Buddhism; it lies within G reek philosophy and within the spirit of the European Renaissance. The real revolution today lies in the popular demand for lifelong education, not in the idea itself ... (G elpi, 1985, p. 18)

The concept of lifelong education was promoted in the late 1960s and 70s by UNESCO (T uijnman \& Boström, 2002) as part of its 'Education for All' campaign. ${ }^{3}$ John Field (2001) states that, as with many 1960s ideas: 
... it drew on the radical thinking of the student movement, the work of post-independence intellectuals in the 'T hird World' and the post-industrial rhetoric of future-gazers like Alvin T offler. (F ield, 2001 p. 4).

We would add that this was also a climate characterised by disillusion concerning schools. There were disillusions concerning the promise they held out, in the liberal 60 s, for being institutions that would bring about a certain degree of social levelling, social justice and social cohesion. D uring this period, serious questions were being asked of the school and other educational institutions regarding their ability to help bring about a greater distribution of resources, democratise knowledge and create a genuinely 'meritocratic' society. T he fundamental tenets of the structural-functionalist view of schooling were being refuted, in sociological interpretations, through the emergence of various schools of thought including those that found relevant explanatory power in M arxism.

\section{The UNE SCO literature}

It is against this climate of trenchant criticisms of schools that one ought to consider UNESCO's adoption of 'lifelong education' as 'a master concept for education policies' (Skager, 1978, p. 3) launched by the Edgar Faure report, L earning to be (Faure et al., 1972, p. 182). Education had to be 're-conceptualised' (Wain, 1985, p. 4; 2004b, p. 86) in view of the widespread disillusion with traditional schooling.

A number of writers constituting a 'movement in the world of education' (Wain, 1987 , p. 35) gravitated around this concept of lifelong education. There were those who drew on scientific-humanism, embraced by UNESCO (see F aure et al., 1972, p. 146) under the influence of Julian H uxley, its first D irector-G eneral (see Finger \& Asún, 2001, p. 22). There are liberal and radical strains within the writings of those associated with the movement, Ettore Gelpi (see M ayo, 1997, pp. 28, 29) and Bogdan Suchodolski featuring among the more radical writers.

The movement focused on and foregrounded the need to see lifelong education as 'an all embracing policy blueprint for education' (Wain, 1982, p. 7). Lifelong education is said to cover different stages of a person's life 'from the cradle to the grave', to use what has now become a cliché in the area, adopted also at the outset of the M emorandum.

L ifelong education often began to be used interchangeably with adult education, probably because it underlines those aspects of learning and pedagogy that occur outside the domains of formal learning institutions. It is 'neither time-conditioned nor space conditioned' (G elpi, in M ayo, 1985, p. 2). A. J. C ropley and others used the term 'lifewide learning' that has recently been regaining popularity in the lifelong learning discourse, with reference to the other educational sources to which one is exposed at different stages throughout one's life (Cropley, 1980, p. 4). This notwithstanding, writers associated with the lifelong education movement also attached importance to the school with respect to their notion of a 'learning society'. 
Schools will need to become agencies in which the foundation for lifelong education is laid.

(Cropley \& Dave, 1978, p. 21)

These writers argue that, rather than arming pupils with knowledge that can become obsolete, the school can place the emphasis on decision making skills, dialogue, participation and one's ability to take charge of one's own learning. The notion of self-directed learning is, of course, one of the most popular notions to emerge from the lifelong education discourse. This is very much an individualistic notion of learning that renders people responsible for their own education, a notion that, in more recent years, has been coupled with that of autonomy.

The 'learning society' (the Faure report conceives of nations as having the potential to become 'learning societies', Faure et al., 1972, p. 263) provides, for many of the authors associated with the lifelong education movement, the context in which much self-directed and lifelong education occurs ( $D$ ave, 1976, p. 34). The learning society is, in this context, often conceived of as futuristic and utopian (see Faure et al., 1972, pp. 163-164). It can be easily criticised on the grounds that it provides a very optimistic view of a 'common humanity' in which difference is subsumed under a single model, according to which a common destiny beckons (Wain, 1987, p. 230). ${ }^{4}$

The lifelong education movement strikes us as being quite variegated with alternative conceptions of lifelong learning and the learning society being provided. It is impossible in such a limited space to do justice to the vast literature on the subject of lifelong education that emerged in the early 1970 s and continued into the early and mid 1980s. The central concept is that of the human being (or 'man' as they wrote at the time) viewed within a humanist conception of individual growth. It was all about 'being' in a world increasingly swamped by the consumer-culture ideology with its emphasis on 'having' (Lengrand, 1970, p. 59).

The Faure report presented a similar view; education, in its normative sense of providing 'worthwhile' knowledge, can enable persons to become beings in process, 'incomplete' beings in the process of becoming in 'an unending process of completion and learning' (F aure et al., 1972, p. 157). In many of the writings, one obtains the sense that the concept has rather individualistic connotations, incorporating the notion of self-directed learning. $D$ ave, however, makes a brief passing reference to the 'collective' (D ave, 1976, p. 4). One wonders whether we should add, in this context, references to the notion of collectively-directed learning in addition to the individualising concept of self-directed learning. The former concept would emphasise the collective dimension of knowledge for change that authors such as Ettore Gelpi (2002) and David W. Livingstone (see Livingstone, 1999a, 2004; Livingstone \& Sawchuk, 2004) continued to emphasise until very recently. ${ }^{5}$

Some of the writers within the movement provided radical versions of the notion of learning as 'becoming'. In one of the more radical versions of lifelong education, underpinned by M arxian thought, Bogdan Suchodolski (1976, p. 95) who broached such topics as the media and consumption (see also Gelpi, 1985b), underlined the need to counter the hegemonic two-dimensional contemporary view of human beings. T he reductionist view is that of people being producers and consumers. 
The concept of an 'education-centred society' promises to show the way out of the hopeless situation resulting from the 'producing society' and the 'consuming society'. K eeping the restraints and obligations imposed on society by production and consumption within rational boundaries, this new concept manifests the profound values of the human existence, thanks to an intensification of all human abilities and energies that further the development of the whole personality. (Suchodolski, 1976, p. 64)

In this respect, we would argue that there is material by writers associated with the lifelong education movement (not necessarily all of them) that anticipates some of the more radical alternative conceptualisations of lifelong learning that have recently emerged, in which human beings are presented as social actors rather than as simply consumers-producers ( $M$ artin, 2001, p. 5).

\section{The economistic turn}

The movement of writers on lifelong education associated with U NESC O seemed to have died out in the late 1980s. In the 1970s, it was not only U N ESC O that promoted the idea of lifelong learning, or rather lifelong education, but also the OECD, although the latter placed the emphasis on 'recurrent education as a strategy for promoting lifelong education' (T uijnman \& Boström, 2002, p. 99). Recurrent education is less of an all-embracing concept than lifelong education since it 'came to be associated with policies for the promotion of formal adult education' (p. 99). John Field (2001) provides a good and helpful overview of the further development of this concept as promoted by various intergovernmental institutions. While UNESCO provided a broad use of the concept, OECD reduced it to human capital theory, 'al beit laced with a few dashes of social democracy' (Field, 2001, p. 6). The emphasis increasingly continued to be placed on 'lifelong learning' that marks an important shift in terminology. As T uijnman and Boström (2002) point out, this discursive shift is significant in that it reduces the emphasis on structures and institutions and lays stress on the individual as a person who lies at the centre of the educational process with the potential to take charge of his/her own learning (pp. 102-103). T he emphasis on 'learning' can help drive home the fact that it is not individuals who need to adapt to the institutions and agencies by which they are taught but it is the institutions and other agencies that must adapt to them. The flip side however is that this change in emphasis ties in beautifully with the dominant hegemonic discourse that education and social well being (as in the case of the transition from the welfare state to the 'welfare society') are the responsibility not of the State but of the individual. By implication, any failure in this regard is to be blamed not on the system but on the individual.

The OECD translated 'lifelong learning' into a 'policy goal' (Field, 1998, p. 31). The change in economic climate in the late 1970s, with a 'more fragmented and turbulent labour market' and the growth of consumerism in W estern societies, made the concept of lifelong learning lose much of its appeal (Field, 2001, p. 8). It did reemerge in the 1990s in the one supranational organisation that has the power to influence the educational policies of sovereign states-the EU. Its re-emergence in this context, and in the context of the OECD, has to be seen against the backdrop of 
a world economic system characterised by the intensification of globalisation and the emergence of the neo-liberal ideology.

\section{Neo-liberalism}

M uch has already been written on the ideology of neo-liberalism and its relation to education (see Pannu, 1996; Walters, 1997; Burbules \& Torres, 2000; Dale \& Robertson, 2004; Olssen, 2004; G iroux, 2004). H owever, some recapitulation of its basic tenets, and key related points, would be appropriate since the concept lies at the heart of our critique, later on in this paper, of the M emorandum and the action it inspires. Boaventura de Sousa Santos states, in the interview with Dale and Robertson (2004), that:

$\mathrm{N}$ eoliberalism is the political form of globalisation resulting from U S type of capitalism, a type that bases competitiveness on technological innovation coupled with low levels of social protection. (de Sousa Santos, in Robertson and D ale, 2004, p. 151)

H e goes on to state that:

The aggressive imposition of this model by the international financial institutions worldwide not only forces abrupt changes in the role of the state and in the rules of the game between the exploiter and the exploited ... but also changes the rules of the game among the other kinds of developed capitalism. (de Sousa Santos, in Robertson and D ale, 2004, p. 151)

Since the early 1980s, neo-liberalism provided the dominant hegemonic discourse surrounding economic development and public policy. It was very much a feature of the Pinochet regime's ideology in C hile, ${ }^{6}$ T hatcherism, Reaganomics (Pannu, 1996), the IMF's and World Bank's structural adjustment programmes in much of the industrially underdeveloped world (Pannu, 1996; Boron \& T orres, 1996; M ulenga, 1996) and the WT O's polices that would also affect educational 'services' (Rikowski, 2002). It is now also a feature of parties in government that have historically been socialist. The presence of this ideology on either side of the traditional political spectrum in Western democracies testifies to the hegemonic nature of neo-liberalism. This point is worth keeping in mind with respect to the M emorandum and its social-democratic trappings.

The presence of the neo-liberal ideology in education, as well as in other spheres of activity, can easily lead one to think and operate within the logic of capitalist restructuring. This process is generally characterised by such features as that of delinking the economic from the social and converting what were once public goods (education and health among them) into consumption goods, as the 'ideology of the marketplace' holds sway. $\mathrm{Neo-liberal} \mathrm{thinking} \mathrm{brings} \mathrm{in} \mathrm{its} \mathrm{wake} \mathrm{increasing} \mathrm{privatisation} \mathrm{and}$ related cuts in public spending on social programmes, together with increased user charges and cost recovery policies, therefore limiting popular access to health, education and other social services. It also leads to public financing of private needs and places the onus for social and economic survival on individuals and groups. It also leads to a decline in real incomes that turns the whole question of 'choice' into a farce 
as people who cannot afford to pay for educational and health services are fobbed off with an under-funded and therefore poor quality public service in these areas. $\mathrm{N}$ eoliberalism also entails a deregulation of commodity prices and the shift from direct to indirect taxation (Boron \& Torres, 1996; Pannu, 1996; M CG inn, 1996). Its orthodoxy also includes, as indicated by $M$ ark Olsson (2004, p. 241), the opening of borders, floating exchange rates, abolition of capital controls, liberalisation of government policy, developing integrated private transnational systems of alliances and establishing, within countries, central banks that 'adopt a market-independent monetary policy that is autonomous of political interference' (ibid.). With respect to the US, H enry A. Giroux refers to the economist William Greider who argues that neoliberalism proponents:

... want to 'roll back the twentieth century literally' by establishing the priority of private institutions and market identities, values and relationships as the organising principles of public life. (Giroux, 2004, p. 107)

The foregoing are, in the main, features of one particular kind of globalisation, often referred to as hegemonic globalisation ( $D$ ale $\&$ R obertson, 2004, p. 148). T his is not the only kind of globalisation in existence. There is also 'counter-hegemonic' globalisation (de Sousa Santos, in D ale and Robertson, 2004, p. 150) or 'globalisation from below' (M arshall, 1997). This consists of acts of resistance against the 'tyranny of the market' (Bourdieu, 1998), partly manifested through empirical observations (Bourdieu, 1999), and:

... resistance against hegemonic globalisation organised (through local/global linkages) by movements, initiatives and NGO's, on behalf of classes, social groups and regions victimised by the unequal exchanges produced on a global scale by neo-liberal globalisation. (de Sousa Santos in D ale and Robertson, 2004, p. 150)

This distinction ought to be born in mind in any discussion of a policy promoted by an institution such as the EU that is not monolithic and, as we shall argue, allows room for alternative and potentially counter-hegemonic conceptions of lifelong learning.

\section{The EU's involvement with lifelong learning}

M urphy (1997), Field (2001, 2002) and Brine (1999), among other writers, trace the development of the EU 's involvement in lifelong learning. M urphy (1997) traces the origin to the publication of Education for life: a European strategy by the European Roundtable of Industrialists. This coincided with a world scenario characterised by the intensification of globalisation entailing mobility of both labour and capital across different boundaries. The onset of neo-liberal policies in different spheres of life led to education being conceived of mainly in vocational terms. In the EU 's case, education serves as a means of bringing nations together to pool their educational infrastructural resources. T he intention is to render their societies competitive in the face of the transnational and multinational corporations' ability to reap the advantages of economies of scale through the expansion of international capital mobility (M urphy, 
1997, p. 363). In the Executive Summary of its document, M aking the E uropean area of lifelong learning a reality, the $\mathrm{C}$ ommission states:

... the current uncertain economic climate places renewed emphasis and importance on lifelong learning. Traditional policies and institutions are increasingly ill-equipped to empower citizens for actively dealing with the consequences of globalisation, demographic change, digital technology and environmental damage. (CEC, 2001, p. 3)

This language is very similar to the jargon used by the then US U ndersecretary of Education, M arshall Smith, who, in 1995, implored that schools should meet the 'ever changing challenges of international competition and the changing workplace' (quoted in $\mathrm{H}$ ursh, 2001, p. 5).

Concerns arising from the changing scenario, characterised by the intensification of globalisation, were already reflected in the EU 's 1994 W hite Paper on competitiveness (CEC, 1994), the 'linchpin of post-1994 economic, social, education and training policy' (Brine, 1999, p. 83). Lifelong learning was accorded importance in this White Paper (see Field, 2002, p. 4; W addington, 2002, p. 160):

\footnotetext{
Preparation for life in tomorrow's world cannot be satisfied by a once-and-for-all acquisition of knowledge and know-how. ... All measures must therefore necessarily be based on the concept of developing, general ising and systematising lifelong learning and continuing training (White Paper in F ield, 2001, p. 10).
}

The 1992 European U nion Treaty, better known as the M aastricht Treaty, accorded the EU 'partial jurisdiction over educational matters' (M urphy, 1997, p. 362). T his amounted to, in Jackie Brine's words (1999), a ' still narrowly defined legal competency in the field of education' (p. 53). D ale and R obertson (2002) note that, since the mid 1990s, there has been

... increasing emphases at all levels of the EU 's work on promoting the knowledge economy and lifelong learning, in which education is taken to be central. ( $D$ ale $\&$ Robertson, 2002, p. 28)

This period saw the White Paper on education and training, entitled Teaching and learning. T owards the learning society (CEC, 1995). This led to the activities of 1996, designated by the EU as the European Y ear of Lifelong L earning. The idea of a 'learning society', which was central to the lifelong education movement's reconceptualisation of education, thus became a key concept in an important EU policy document; it has remained so ever since. As indicated earlier on, the Commission stated that it is on the basis of the 'conclusions' reached during the events of the E uropean $Y$ ear of $L$ ifelong L earning that the $M$ emorandum was issued in $N$ ovember 2000 . We now turn to a consideration of the $\mathrm{M}$ emorandum.

\section{The EU Memorandum on lifelong learning: some considerations regarding its main themes}

The M emorandum has four basic objectives, namely those of (a) active citizenship; (b) social inclusion; (c) employability; (d) personal fulfilment. ${ }^{7}$ These M emorandum 
objectives emerged from the conclusions of the $\mathrm{H}$ eads of $\mathrm{M}$ ember States meetings in Lisbon and Santa M aria da Feira in 2000. They are intended to strike a balance between the demands of a changing economy and a changing social environment. And all this is to occur in the context of a changing global economic and demographic scenario, involving, in the latter case, the constant mobility of labour power across borders and not necessarily EU borders.

The $\mathrm{M}$ emorandum adopts, on its very first page, the following definition of lifelong learning:

... all purposeful learning activity, undertaken on an ongoing basis with the aim of improving knowledge, skills and competence. (CEC, 2000, p. 3)

This definition was formulated within the context of the European Employment Strategy initiated at the $\mathrm{H}$ eads of State European Council held in L uxemburg in 1997 (CEC, 2000, p. 3). This definition led to concerns, voiced during the consultation process, that too much emphasis was placed on the employment and labour market aspects of lifelong learning (CEC, 2001, p. 9). The definition was subsequently broadened to read thus:

... all learning activity undertaken throughout life, with the aim of improving knowledge, skills and competences within a personal, civic, social and or/employment-related perspective.

The social dimension of lifelong learning was thus recognised, reflecting an appreciation of the different facets of the human and collective being.

$T$ his section incorporates features and terminology that hearken back to the writings of the lifelong education movement, including the term 'lifewide learning' (CEC, 2000, p. 9). All this of course remains at the level of a policy document. $\mathrm{H}$ ow do these policy formulations translate into action throughout Europe? We therefore engage in a discussion regarding some of these actions at the European and national levels.

\section{A critical review of 'relevant' action}

The document entitled $\mathrm{N}$ ational actions to implement lifelong learning in Europe, produced jointly by the Eurydice European U nit (EEU) and Cedefop, provides an overview of action undertaken to promote lifelong education and training at the E uropean level and in different European countries. This is in accordance with the M emorandum's objectives. What follows is an attempt to analyse the concrete manifestations of the discourse on lifelong learning, as showcased by this document. In her 'Preface' to the document, Viviane Reding, Commissioner, Education and Culture, is rather explicit in her belief that lifelong learning should mainly be concerned with economic competitiveness. Reding insists that:

If we wish educational standards in Europe to be among the best in the world, it is vital to adjust our educational systems to the requirements of the economy and the knowledge society. (C edefop \& E urydice, 2001, p.5)

Reding's view of the projects surveyed by the E urydice-C edefop team is that: 
... many initiatives are now moving in this direction, and that European cooperation is also contributing to such an adjustment. (C edefop \& Eurydice, 2001, p. 5)

In general, what emerges from a detailed look at the document is that there seems to be a marked difference between the concrete interpretation of some of the main themes at the European level and the type of projects developed at the national level. While the key words at the European level are labour market, employability, flexibility and mobility, the general concern at the national level seems to be with balancing market interests with personal and social needs. The rest of the paper builds on this observation.

\section{New basic skills}

The concern with employability, flexibility and mobility of Europe's human resources is clearly manifested in the projects that address basic skills. In the summary leading to the detailed description of the projects dealing with the above theme, the authors remark that:

... the structures underlying education are changing as entire curricula are reconsidered. Whole sections of systems, if not systems themselves are undergoing thorough reform. The result of gradually more integrated approaches is that arrangements for guidance, support and identification of skills needed by the labour market, in cooperation with the social partners, are highly significant aspects of curricular provision. (C edefop \& Eurydice, 2001, p. 15)

This intimate link between educational provision and the labour market is most explicit at the European level. For example, the Career-space project, launched by seven major ICT companies in Europe, with the support of the European C ommission, sets out to explore new ways of addressing the perceived skills gaps and mismatch arising from the development of the knowledge society. The project attempts to provide a framework for education and training institutions that defines the skills and competences required by the ICT industry in Europe. Its main goals are:

... to attract more students into ICT courses and employment by providing attractive, plain language profiles of the jobs, roles and opportunities in the industry today, to provide higher education ICT curriculum designers with clear up-to-date and easily accessible information on the skills needed by the industry and, finally, to assist governments in developing policies to foster the growth of ICT skills in Europe. (C edefop \& Eurydice, 2001, p. 17)

While the cutting edge of the high tech sector constitutes the main concern of the C areer-space project, the aim is to redefine the needs at all levels in all sectors, as:

... computers and ICT specialists are needed across the broad spectrum of industries and services today. (C edefop \& Eurydice, 2001, p. 17)

The European Commission's 'N ew Strategy on Building N ew European Labour M arkets by 2005' set up a high level skills and mobility taskforce, in A pril 2001, to: 
... identify the main drivers and characteristics of the new European $L$ abour market, with a particular focus on skills, lifelong learning and mobility. (C edefop \& Eurydice, 2001, p. 17)

The E uropean C omputer D riving Licence (ECD L), launched in August 1996 and now an ICT benchmark in many countries, transcends the need for enhancing knowledge and competence in the use of personal computers and common computer applications within Europe and internationally. In the document's own words, the ECD L provides a basic qualification which will increase:

... the productivity of employees who use computers in their work, enabling better returns from investments in IT . (C edefop \& E urydice, 2001, p. 17)

The common thread that weaves through the Actions at E uropean level, as shown above, is the attempt by private enterprise and industry to construct a 'skills crisis' in Europe rather than a 'jobs crisis' ( $M$ arshall, 1997, p. 59). ${ }^{8}$ This perceived gap, coupled with a persistent call on the education community to render its operation more relevant, is forcing public institutions to redefine their educational outcomes and priorities in the process of curriculum design, development and implementation. The net result of this European hysteria around ICT skills ${ }^{9}$ is an increase in public financing of private needs in an area of human resources that is crucial to latter-day capitalism. Private and public interests, concerns and agendas are slowly becoming one. This particular excerpt reveals the extent to which public institutions are willing to accommodate industry's needs.

A number of Member States have completely overhauled their VET systems and replaced them with competence-based systems. Such core curricula often try to find the right mix between general education subjects, generic skills, and specific or technical skills for a particular occupation or job. This is seen as part of the provision of a wide foundation for lifelong learning in initial education and training, in particular, a broad skills base on which to develop one's career and employability. (C edefop \& Eurydice, 2001, p. 18)

At this point, the discussion on what constitutes basic skills becomes crucial. In the context of post-secondary, particularly vocational education, the document underscores the importance of the highly diffused area of ICT, which is closely associated with moves towards the 'information society' and the needs of a 'knowledge economy'. It also indicates the various models that have been proposed in Europe for the adaptation of content and curricula. One model, the approach promoting basic, generic and core skills (C edefop \& E urydice, 2001, p. 31), is mainly a characteristic of English-speaking countries; it is also seen, albeit to a lesser degree, in a number of other countries (Denmark, N etherlands, Germany, Finland). The skills promoted within this approach are:

... the general el ementary and/or cognitive competences required for a whole series of jobs, indeed all jobs: mathematics, reading, writing, problem-solving, social, communication and interpersonal competences. They are entry skills to gainful work and employment as well as skills necessary for social participation (citizenship). (C edefop \& Eurydice, 2001, p. 31) 
The other approach, referred to, in the document, as the approach promoting transferable (key) competences and broad professional competence (Denmark, Germany, I taly and Austria), is based on:

... a collection of competences transcending divisions of labour and traditional occupational profiles. The competences cited are social and communication competences, and strategic efficiency, in particular problem-solving competences, organisational competences and leadership. (C edefop \& Eurydice, 2001, p. 31)

What is striking in both approaches is the intimation that the skills required for success in the market economy are the same skills necessary for active citizenship. Recall that the development of active citizenship constitutes one of the key objectives of the $\mathrm{M}$ emorandum. A productive life within the economy seems to be perceived as an integral feature of what constitutes active citizenship. This is in keeping with the narrow definition of citizenship favoured by those Bill Williamson (1998), echoing Robert Boguslaw, calls the 'new utopians' (managers, technocrats, IT specialists, etc). Williamson argues that their vision is gaining the ascendancy, despite the fact that he regards such a vision as having no 'humane centre', being a 'systems view of the world'. T his systems view is:

... in its unintended outcomes ... corroding the whole social fabric of modern society. (Williamson, 1998, p. 91)

The above inserts from the Cedefop-Eurydice document tend to suggest that the educated citizen, echoing the 'new utopian vision', is one who can easily transfer a set of skills from the economic to the social zone of a given public sphere. M orrow and Torres (2000) assert that:

To drastically overhaul educational systems on the basis of such problematic assumptions about the post-Fordist workplace may be in the immediate interests of many types of employers, but it is not clear that it will effectively serve the broader interests of society, let alone workers in general. The overall effect is to shift education toward competence-based skills at the expense of the more fundamental forms of critical competence required for autonomous learning and active citizenship. (M orrow $\&$ T orres, 2000, p. 47)

The transformation of education to address industry's most updated needs is not only evident in curricular visions and course programmes, but is also reflected in the attempt to create more flexible and open spaces. T hese spaces are aimed at providing individual learners (read: actual and/or potential workers) with opportunities to combine production with predominantly training needs. According to this document:

$\mathrm{N}$ ew learning environments are being promoted which encourage self-directed learning.

This will be achieved through enhanced individual learning pathways, flexibility and modularised structures which will allow accreditation of smaller programme sequences, thus enabling students to change track. Formulation of a personal education plan contributes to meeting individual learning needs and to developing personal competences. (C edefop \& Eurydice, 2001, p. 18)

O nce again, industry's most pressing needs are here presented as 'individual learning needs'. The pedagogy of self-direction is promoted as the system's attempt to 
accommodate the individual. In essence, it is a strategy that ensures the availability of an 'army of workers' that is constantly updating itself. The process of the privatisation of the learner, financed mostly by public funds and close to market needs, is well underway. Such a strategy could well result in the marginalisation of non marketoriented educational provisions (C urrie \& Subotzky, 2000).

\section{Human resources}

The document is rather explicit in its critique of the level of investment in human resources. It states that:

If one compares national figures from the OECD 's report 'E ducation at a glance', over the past ten years, one finds that no great increase in spending has taken place. (C edefop \& Eurydice, 2001, p. 45)

Efforts to invest heavily in new areas of lifelong learning, e.g., investments in preschool education, have meant that other areas:

... have experienced budgetary cuts, such as higher education and vocational training.

(C edefop \& Eurydice, 2001, p. 45)

It is clear that most governments are unable to sustain this key message on their own. Countries are increasingly turning to employers and individuals to invest more in education and training. As far as individuals are concerned, the document reports under-utilisation of schemes that encourage individuals to invest in their own learning. Clearly, shifting the burden of financing education on to the individual is taxing on many, 'particularly those with family commitments, etc, who have to take a cut in income' (Cedefop \& Eurydice, 2001, p. 46). On the other hand, where companies have intervened financially, programmes are mostly competence-based and are strictly tied to their immediate training needs.

At the European level, the four structural funds are all set to reduce the gap in living standards between the peoples and regions of the EU. While this common mission ought to be applauded, such funds resemble the welfare compromise within a capitalist context. Structural funds might alleviate the gap between 'haves' and 'have nots'. They would not contribute, however, towards eliminating the structural problems caused by an asymmetrical and socially differentiating socio-economic system.

Dependency is another issue that is often overlooked in European circles. The European Social F und (ESF) constitutes the EU 's financial instrument for investing in human resources. ESF focuses mainly on employment opportunities. In fact, the guiding principles of ESF are employability, entrepreneurship, adaptability and equal opportunities.

Some member states are receiving huge amounts of ESF cash for their programmes to the extent that they have become ESF dependent. With the share of ESF expenditure rising to $40 \%$ in some member states, one can refer to such funding and consequent dependency as a new form of neo-colonialism. Some member states are losing their control over large chunks of their educational programmes, as local educational leaders have to operate within ESF parameters. The ESF is a major source of funding 
for N GO's involved in adult education that cannot depend any longer on the national or local state institutions for financial support. M oreover, such cash tends to alienate the very victims of the present socio-economic arrangement. The focus is mainly on the liberal notion of 'equal opportunities' within a 'meritocratic' system rather than on a socially just and equitable context where the notion of equal outcomes dominates over vertical equality.

A nother trend linked to this theme is that of the 'individual learning account'. While models differ in details, all are currently based on the idea that different partners, including the state and employers, contribute to the individual's 'learning account'. There is always the danger that the notion of shared responsibility, currently being practised in the UK, the N etherlands and Sweden, could one day follow the health and pensions' track and become an individual rather than a shared concern.

\section{Innovation in teaching and learning}

At the European level, educators and trainers seem to have been the prime targets of innovation. The eL earning I nitiative, for example, sets out to train European teachers in digital technologies, thereby accelerating their networking potential. The T hematic $\mathrm{N}$ etwork in Teacher Education (TNTE) and the Training of Trainers N etwork ( T T net) constitute two examples of the digital contribution to transnational dialogues and potential mobilisation.

At the national level, the main areas of innovation are individualised programmes for unemployed youths (e.g., Job F actory in Austria), programmes for young people who encounter difficulties in pursuing education at upper secondary level (e.g., individualised programmes in Sweden), on-the-job training, vocationally-oriented upper secondary programmes (e.g., the pilot project for advanced vocational education in Sweden), the development of teaching and learning methods based substantially on ICT (e.g., digital campuses in F rance and FAS $\mathrm{N}$ et College in I reland), distance learning for Adults (e.g. $\mathrm{N}$ ational Schools for Adults in Sweden) and huge investments in ICT in schools (e.g., $\mathrm{N}$ ational Plan for Educational Technologies in Italy and the $\mathrm{N}$ ational $\mathrm{G}$ rid for Learning in the $\mathrm{UK}$ )

F rom the above list, one can easily deduce that ICT is perceived as central to innovation in education and training. ICT is said to improve flexibility, independence and access to learning. Huge efforts and money have thus been invested in connecting people electronically and in addressing their individual needs. W hat emerges clearly, from the document's description of the projects that address key message three, is the huge electronic divide that seems to be occurring between European countries with high GD Ps and others that lag behind. ICT is therefore not only privatising learning but is clearly discriminating in the areas of access and development.

\section{Valuing learning}

The rhetoric informed by this theme focuses on: 
... creating bridges and articulation between various learning pathways, enabling more movement between work and school and vice versa, and most importantly, valuing and making visible in terms of documentation or qualifications the results of learning taking place in non-formal settings. (C edefop \& Eurydice, 2001, p. 94)

While the documentation and recognition of non-formal learning constitutes a central theme of a number of national initiatives at the European level (e.g., EVC in the $\mathrm{N}$ etherlands, ANEFA in Portugal and The Competence Reform Forum in $\mathrm{N}$ orway), most of the efforts are directed at improving the mobility of human capital. $T$ he homogenisation of standards, leading to a more efficient processing of qualifications, is perhaps one of the most ambitious and far reaching efforts ever undertaken by capitalism in the area of education. Homogenisation of standards constitutes an integral part of globalisation and of the emergence of a new policy consensus globally within education (Lingard, 2000, p. 83). In the not too distant future, the plastic education credit card will provide readily available proof of one's educational and/or vocational accumulation. Screening for employment will become a matter of minutes.

At the European level, Leonardo and Socrates programmes have financed a number of largely 'unsuccessful' projects aimed at developing automated assessment in basic skills, technical and vocational skills and key skills. The European Computer $D$ riving $L$ icence $(E C D L$ ) constitutes a highly successful attempt to homogenise ICT learning across countries. While ECD L can be described as a 'success story', the fact that ECDL is limited to competences that can readily be measured in an 'objective' manner is indicative of the restricted nature of the whole undertaking. In the document's own words, the ECDL overlooks:

... key competences such as those linked to communication, cooperation and problemsolving. (C edefop \& Eurydice, 2001, p. 95)

The E uropean C redit T ransfer System (ECTS) is aimed at recognising academic studies abroad. Efforts are underway to develop ECTS into a European Credit System that allows for accumulation and transfer within a lifelong learning perspective. The Bologna D eclaration refers to the establishment of a system of credits as in the ECT S system.

Other efforts to standardise qualifications include: the certificate supplement that is aimed at providing a standardised format for present skills and competencies acquired by holders of a certificate; the development of a Common European CV; and the Europass training which provides personal details as well as details regarding training.

\section{E ducation and the community}

The adoption of this theme, particularly through the concept of 'learning regions,' entails a strategy of reaching out to stakeholders within the community and working with them on tailor-made learning approaches in their own environment. Initiatives have taken various forms and shapes. In Italy, 'all the recent reforms seek to build a closer relationship between schools and the community' (C edefop \& E urydice, 2001, 
p. 134). In the UK, the $N$ ational $N$ eighbourhood Renewal Strategy-A $N$ ational Strategy Action Plan aims at stopping the decline in the country's poorest regions. Other initiatives are taking the shape of economic-oriented partnerships (e.g., regional agents in the $\mathrm{N}$ etherlands and Skillsnets in the UK). There are also local initiatives with social objectives (e.g., Building L earning Communities in the Basque Region and $\mathrm{M}$ ission Locales in F rance).

Such strategies, while genuinely predicated on the idea that community-oriented initiatives address the real needs of community members, tend to assume that people with competing interests can override their differences and work together. Community workers know only too well that this is neither always possible nor always desirable. In certain situations, particularly where power relationships are asymmetrical, consensus often militates against the interests of marginalised groups.

\section{Conclusion}

The EU M emorandum on lifelong learning and a number of projects it inspired indicate, in no uncertain terms, the extent of the distortion that has occurred with respect to the once humanistic concept of lifelong education as propounded by the movement of writers discussed earlier. Some of the humanistic considerations, together with those of other writers, were co-opted in the service of a document seeking to provide a humanistic facade to what is, in effect, a neo-liberal inspired set of guidelines. The humanistic facade indicates that, with respect to EU policy making:

... many ideas are possible in principle and float around in a 'policy soup' in which specialists try out their ideas in a variety of ways. (K ingdon, cited in Richardson, 2001, p. 18)

The 'policy' or 'primeval' soup, however, has one predominant compound, that of neo-liberalism, which is brought about by the 'proposals that survive to the status of serious consideration', proposals that:

... meet several criteria, including their technical feasibility, their fit with dominant values

... their budgetary workability, and the political support or opposition they might

experience. (K ingdon, cited in Richardson, 2001, p. 18)

The neo-liberal set of guidelines, contained in the $\mathrm{M}$ emorandum, serves to heighten the member countries' and candidate countries' competititvity in a scenario characterised by the intensification of globalisation. As far as the concept of lifelong learning is concerned, we would argue that the old wine has been placed in new bottles, but has been adulterated in the process. Is this yet another example of capitalism's dynamism being reflected in its ability to appropriate a potentially oppositional discourse?

O ne immediate response to this question would be to point out that the underlying liberal notions of some of the 'old' literature related to lifelong education, bereft, in a number of works, of a collective dimension, with an individualistic emphasis on 'selfdirected learning', paved the way for this distortion and neo-liberalisation of the concept, as propounded in the EU M emorandum. 
This notwithstanding, there are resources and spaces of hope. ${ }^{10} \mathrm{No}$ hegemonic arrangement is ever complete and there can be spaces within the interstices of organisations that allow possibilities for counter-hegemonic work. The EU is no exception. Like all institutions, it is not monolithic and its processes of policy making are quite complex.

L obbyists of different stripe engage in 'venue shopping' as they pursue different avenues for policy making, within the EU, to get their ideas across. For instance, as Sonia M azey and Jeremy Richardson point out, when:

... groups fail to gain satisfaction at the national level, the Commission, the $\mathrm{P}^{11}$ or $\mathrm{C}$ oun-

cil of $\mathrm{M}$ inisters, they have the option-albeit a costly one- of bringing cases ... before the

Court. ${ }^{12}$ (M azey $\&$ Richardson, 2001, p. 231)

The two authors indicate how groups in connection with 'old' (trade unions) and 'new' social movements (women's and environmental groups) have been successful in securing favourable ECJ decisions that have conditioned policy change (ibid.). It is conceivable that similar lobbyists within the educational field can condition the language of EU policy documents including those on lifelong learning. These lobbyists would include humanist-oriented education 'experts' within various EU 'epistemic communities', including working groups in connection with various 'actions', as well as groups sounded out during the consultation process. They could well strike a blow for those aspiring to an alternative conception of lifelong learning, one that retains a humanistic core. These lobbyists can operate at different venues and stages of policy-making, including the consultation process itself. Recall that the $M$ emorandum's definition of lifelong learning was modified in the document, $M$ aking the European area of lifelong learning a reality (CEC, 2001). This was the result of a negative reaction, during the consultation process, to the $M$ emorandum's strong vocationally oriented definition of lifelong learning.

As for the old U NESCO related lifelong education movement, we have also shown that, for all the individualistic strains of much of its literature, it was quite variegated. There were dissenting leftwing voices (see Suchodolski, 1976; G elpi, 2002) providing insights and visions of humanity that project an expansive view of people with a range of subjectivities extending beyond the production-consumption nexus. Theirs is the kind of vision called for by Williamson (1998). The concerns manifested by the dissenting voices within the old UNESCO literature continue to be expressed at meetings held by the same organisation. D uring the Fiftieth meeting of the Council of the International Bureau of E ducation, several participants reacted to the presentation of the OECD's possible scenarios for education in the twenty-first century by referring to the league-tables that are dotting the international education landscape. In the view of a significant number of participants at the meeting:

The convivial quality of education should not be subordinate to its instrumental quality. In this view, a country's quality of education, for example, would not be defined ... by the place it has achieved in tests evaluating quantifiable results that are comparable in contents, values and instrumental skills, but by the way in which that education contributes to guarantee peace, life in common and social cohesion. (IBE, 2004, p. 184) 
When allied with the insights of authors who stress the collective dimension of a transformative education and citizenship, some of which Brine (1999, p. 152) and others find in the radical tradition of adult education (see, for example, literature in connection with N ALL, PEN and similar networks ${ }^{13}$ ), this section of the 'old' literature can make a useful contribution to the development of an alternative and emancipatory conception of lifelong learning. This is the sort of conceptualisation that places emphasis on social actors working and learning collectively in specific local sites and across international boundaries. They would articulate their local experiences with those of larger international movements (they can avail themselves of electronic networking, EU funded mobility programmes and meetings, etc) to partake of and contribute to the second and more edifying type of globalisation mentioned earlier in the paper.

\section{Acknowledgements}

This paper grew out of a section in a chapter on the economics and politics of adult education, co-written by Griff Foley, Shirley Walters and the present authors, that appeared as Walters et al., 2004. This is a much expanded and substantially revised discussion drawing on a wider range of issues and themes from the EU M emorandum on lifelong learning. Earlier drafts of the paper were presented at the 2002 BAICE conference held at the U niversity of $\mathrm{N}$ ottingham, the 1st G E N IE C onference, $\mathrm{N}$ icosia, 2003, and in one of the plenaries at the 6th Conference of the European Sociological Association, M urcia, 2003. We would like to thank our colleagues, D r. M ary D armanin, Professor Ronald G. Sultana and Professor Godfrey Baldacchino for their most valuable comments on earlier draft versions of this paper. D r. D armanin's sharing with us of her books on EU policy making and Professor K enneth W ain's sharing of sections of his 2004a book manuscript (prior to publication) are very much appreciated. We also thank the participants at the 2003 GEN IE Conference at N icosia and those who attended the relevant sessions at the BAICE and ESA conferences for their insightful feedback on this work. Any remaining shortcomings are our responsibility.

\section{Notes}

1. Council Conclusions of 20 D ecember 1996 on a strategy for lifelong learning (97/C 7/02).

2. The general rhetoric concerning lifelong learning does not necessarily translate, in practical terms, into adequately funded initiatives and appropriate structures outside the domain of schooling as several persons would point out with respect to various countries and regions of the world. See, for instance, Schugurensky (2001) with respect to Latin America and adult education policy making there (p. 528) and the contributions of several participants at a 2002 conference on adult education in the East M editerranean with respect to the situation obtaining in their countries ( $M$ ayo, 2002, p. 126; M edic, 2003, p. 70, N ikolovska, 2003, p. 57).

3. T uijnman and Boström (2002) provide a comprehensive account of U N ESC O's promotion of this concept, giving importance to the role U NESC O 's I nstitute of E ducation in H amburg and its academic journal, the International R eview of E ducation, played in the relevant debates on the subject. 
4. Wain refers to an alternative model of the learning society proposed by those members of the second wave of 'pragmatist' writers who 'are ready to reverse all these tendencies, to take different societies as they are' and who 'are thus ready to argue that there is not any one model of such a society that can be universally imposed, and that the shape any "learning society" will take depends upon an ongoing dialectical relationship between the ideological, economic, cultural, educational features that it already has ...' (Wain, 1987, p. 230). Wain includes G elpi among those who favour a pragmatist approach to lifelong education: a historical and comparative approach with the emphasis being placed less on this concept's future possibilities and more on the actual present day reality of lifelong education (Wain, 2004a, p. 19).

5. Maybe Joan Bofill's (1985) notion of education as participation, conceived of within the context of communal participation in a region emerging from a recent history of totalitarianism and cultural suppression (C atalonia in the immediate post-F ranco years) also comes close to this conception of directivity in learning.

6. International guidelines for a market economy were introduced in Chile in 1975, with most of the influential members of the relevant ministry having been products of the U niversity of Chicago (they were referred to as the ' $C$ hicago boys') and having been strongly influenced by the ideas of M ilton Freidman (Quiroz M artin, 1997, p. 39).

7. It adds an important element (active citizenship) to the 1995 paper (CEC, 1995) which had stressed objectives (b), (c) and (d) when focusing 'primarily, but not unproblematically, on the individual' (Brine, 1999, p. 85).

8. See Livingstone (1999b, 2004) for Canadian data that lend credence to this argument and contradict the claims of those celebrating the arrival of the 'knowledge based economy'. Citing a report by Lavoie and Roy (1998), he argues that 'In spite of fairly rapid growth over this period, knowledge workers still made up less than $10 \%$ of the labour force in 1996. While details of this occupational classification may be disputed, it is clear that the vast majority of the $\mathrm{C}$ anadian labour force continued to be employed in jobs that require fairly routinised transmission of data, processing of goods or provision of personal services' (Livingstone, 2004, p. 8). He argues that while a learning society exists and that there is compelling empirical evidence to support this view, this is not matched by the necessary related economic reforms 'that address basic dimensions of work reform, including the redistribution of paid work time to reduce current polarisation and the democratisation of paid work to give more workers' greater opportunities to apply their extensive acquired knowledge ...' (Livingstone, 2004, p. 19).

9. We subscribe to the view that excessive use of ICT in education can continue to render learning an isolated and individualistic activity. It can diminish the element of human interaction between teacher and taught, regarded as key to a dynamic learning process, one in which knowledge is created and recreated through co-investigation between educators and learners. In the words of M orrow and T orres (2000): 'But there are al so some important arguments that call into question such developments: the cognitive limitations of electronic delivery and computer-based systems of information retrieval based on fragmentation of knowledge; the loss of the critical, reflective side of education in a context driven by individualised packaging and marketing of skills; the contribution of global education to the further breakdown of local communities and educational systems; and the role of global education as part of a broader process of cultural invasion, especially from the developed to the underdeveloped parts of the world' (p. 43).

10. The terms naturally derive from Williams (1989) and H arvey (2000).

11. European Parliament.

12. The European Court of Justice (ECJ).

13. The web site for the Ontario directed project, NALL ( $N$ ew approaches to lifelong learning), directed by David W. Livingstone of the Ontario Institute for Studies in Education/ U niversity of T oronto, is at www.nall.ca. The web site for PEN (Popular education network), 
coordinated by a group of scholars/activists from the University of Edinburgh, is at www.neskes. net/pen.

\section{Notes on contributors}

Carmel Borg is Senior Lecturer and D ean at the $F$ aculty of E ducation, U niversity of $\mathrm{M}$ alta. C armel Borg has co-edited (with Joseph A. Buttigieg and Peter M ayo) $G$ ramsci and education (2004) and is currently co-editing (with Colin Calleja) $\mathrm{C}$ hildren and youth at risk and (with Peter $\mathrm{M}$ ayo) Public intellectuals, radical democracy and social movements. $\mathrm{H}$ e is editor of the $\mathrm{J}$ ournal of $\mathrm{M}$ altese $\mathrm{E}$ ducation Research and co-editor of the J ournal of Postcolonial E ducation.

Peter $M$ ayo is Associate Professor in the Department of Education Studies at the $\mathrm{U}$ niversity of $\mathrm{M}$ alta. $\mathrm{H}$ e focuses on the areas of sociology of education and adult continuing education. $\mathrm{He}$ is the author of $\mathrm{G}$ ramsci, $\mathrm{F}$ reire and adult education (1999) and Liberating praxis. Paulo F reire's legacy for radical education and politics (2004). He is co-editor of B eyond schooling. A dult education in M alta (1997) and G ramsci and education (2004).

\section{References}

Bofill, J. (1985) Participatory education, in: K. Wain, (Ed.) Lifelong education and participation ( $M$ alta, The U niversity of $M$ alta Press).

Boron, A . \& T orres, C . A. (1996) The impact of neoliberal restructuring on education and poverty in L atin A merica, A lberta J ournal of Educational R esearch, XL 11(2), 102-114.

Bourdieu, P. (1998) A cts of resistance: against the tyranny of the market (N ew Y ork, T he N ew Press). Bourdieu, P. (1999) The weight of the world: social suffering in contemporary society (Palo Alto, Stanford U niversity Press).

Brine, J. (1999) Undereducating women: globalising inequality (M ilton Keynes, Open University Press).

Burbules, N . C \& T orres, C. A (Eds) (2000) G lobalisation and education: critical perspectives (N ew Y ork, Routledge).

CEC (1994) E mployment, growth, competitiveness (L uxembourg, Office for Official Publications, Commission of the European C ommunities).

CEC (1995) W hite Paper. Education and training: teaching and learning: towards the learning society (L uxembourg, O ffice for Official Publications, C ommission of the E uropean Communities).

CEC (2000) Commission staff working paper. A memorandum on lifelong learning (Brussels, European Commission).

CEC (2001) Communication from the Commission. M aking a European area of lifelong learning a reality (B russels, European Commission).

Cedefop \& Eurydice (2001) N ational actions to implement lifelong learning in Europe (Brussels, Eurydice)

Cropley, A. J. (1980) Lifelong learning and systems of education: an overview, in: A. J. Cropley (Ed.) Towards a system of lifelong education. Some practical considerations (Oxford, Pergamon Press).

Cropley, A. J. \& Dave, R. H . (1978) Lifelong education and the training of teachers (Hamburg, UNESCO Institute of E ducation).

Currie, J. \& Subotzsky, G. (2000) Alternative responses to globalisation, in: N. P. Stromquist \& K. M onkman (Eds) Globalisation and education: integration and contestation across cultures (L anham, Rowman \& Littlefield). 
Dale, R. \& Robertson, S. (2002) The varying effects of regional organisations as subjects of globalisation of education, Comparative E ducation R eview, 46(1), 10-36.

Dale, R. \& Robertson, S. (2004) Interview with Boaventura de Sousa Santos, Globalisation, Societies and Education, 2(2), 147-160.

Dave, R. H. (1976) Foundations of lifelong education: some methodological aspects, in: R. H. D ave (Ed.) F oundations of lifelong education (Oxford, Pergamon Press).

Faure, E., H errera, F., K addoura, A. R., L opes, H ., Petrovsky, A. V., Rahnema, M . \& Champion Ward, F . (1972) L earning to be. The world of education today and tomorrow (Paris, U N ESC O).

Field, J. (1998) G lobalisation, Social capital and lifelong learning: connections for our times?, in A. Bron, J. Field \& E. Kurantowicz (Eds) Adult education and democratic citizenship II (K rakow, Impulse Publisher).

F ield, J. (2001) L ifelong education, International J ournal of L ifelong E ducation, 20(1), 3-15.

Field, J. (2002) Building a European dimension: a realistic response to globalisation?, in: J. Field (E d.) P romoting E uropean dimensions in lifelong learning (L eicester, N IACE).

Finger, M \& Asún, J. M . (2001) A dult education at the crossroads. Learning our way out (L ondon, Zed Books).

Gelpi, E. (1985a) Lifelong education and international relations, in: K. Wain (Ed.) Lifelong education and participation ( $M$ alta, $T$ he $U$ niversity of $M$ alta Press).

G elpi, E. (1985b) L ifelong education and international relations (L ondon, C room $\mathrm{H}$ elm).

Gelpi, E. (2002) Lavoro Futuro. La formazione professionale come progetto politico [F uture work. Vocational preparation as a political project] (Milan, Edizioni Angelo Guerini e Associati $\operatorname{SpA})$.

Giroux, H. A. (2004) The terror of neoliberalism. Authoritarianism and the eclipse of democracy (Boulder, C O, Paradigm Publishers).

H arvey, D . (2000) Spaces of hope (E dinburgh, E dinburgh U niversity Press).

H ursh, D. (2001) Neoliberalism and the control of teachers, students, and learning: the rise of standards, standardisation and accountability, Cultural L ogic, 4(1). Available online at: http:// eserver.org/clogic/4-1/4-1.html (accessed 15 D ecember 2004).

IBE (2004) Scenarios for education in the twenty-first century: synthesis of an unfinished dialogue and questions for further progress, P rospects, XXXIV (2), 179-195.

Lavoie, M . \& Roy, R. (1998) Employment in the knowledge-based economy: a growth accounting exercise for Canada (Ottawa, Applied Research Branch, Human Resources Development C anada).

Lengrand, P. (1970) An introduction to lifelong education (Paris, U N ESC O).

Livingstone, D . W . (1999a) Exploring the icebergs of adult learning: findings of the first Canadian survey of informal learning practices, Canadian J ournal for the Study of A dult E ducation, 14(1), 49-72.

Livingstone, D. W. (1999b) The education-jobs gap: underemployment or economic democracy (Boulder, W estview Press).

Livingstone, D.W. (2004) The learning society: past, present and future views, lecture presented at OISE/U niversity of Toronto, $14 \mathrm{O}$ ctober. Available online at: www.wallnetwork.ca (accessed 17 June 2005).

Livingstone, D.W. \& Sawchuk, P. (2004) H idden knowledge: organised labour in the information age (Toronto, Garamond Press).

M arshall, J. (1997) G lobalisation from below. The trade union connections, in: S. Walters (Ed.) G lobalisation, adult education and training. I mpact and issues (L ondon, Zed Books).

M artin, I. (2001) Reconstituting the agora: towards an alternative politics of lifelong learning, Concept, 2(1), 4-8.

M ayo, M . (1997) I magining tomorrow. A dult education for transformation (Leicester, NIACE).

M ayo, P. (1985) Ettore G el pi and lifelong education, The Teacher, O ctober, 2-3.

$M$ ayo, P. (2002) East M editerranean cooperation in adult education. R eflections on the two day international conference Exploring possibilities of international cooperation in the field of adult 
education in the Eastern M editerranean, Ayia N apa, Cyprus, 24-25 M ay 2002, M editerranean J ournal of E ducational Studies, 7(1), 125-131.

M azey, S. \& Richardson, J. (2001) Interest groups and EU policy-making. Organisational logic and venue shopping, in: J. Richardson (Ed.) European Union. Power and policy making (L ondon, Routledge).

M cG inn, N . F . (1996) Education, democratisation and globalisation: a challenge for comparative education, Comparative E ducation R eview, 40(4), 341-357.

M edic, S. (2003) Conditions, problems and measures of support for adult education in Serbia, in: P. M ayo, K. Symeonides \& M. Samlowski (Eds) Perspectives on adult education in the M editerranean and beyond (Bonn, IIZ-DVV).

M orrow, R. \& T orres, C. A. (2000) The state, globalisation and educational policy, in: N. C. Burbules \& C. A. Torres (Eds) Globalisation and education: critical perspectives (L ondon, Routledge).

M ulenga, D. (1996) The impact of economic crisis and structural adjustment on education and training in Africa, in: $\mathrm{H}$. Reno \& M. Witte (Eds) Thirty-seventh annual adult education research conference proceedings ( $T$ ampa, U niversity of South F lorida).

M urphy, M . (1997) C apital, class and adult education: the international political economy of lifelong learning in the European U nion, in: P. Armstrong, N . M iller \& M . Zukas (Eds) C rossing borders. B reaking boundaries: research in the education of adults, proceedings of the twenty-seventh annual SCUTREA conference (L ondon, Birkbeck College).

Nikolovska, M. (2003) Adult Education in the Republic of M acedonia: Present conditions and priorities, in: P. M ayo, K. Symeonides \& M. Samlowski (E ds) Perspectives on adult education in the M editerranean and beyond (Bonn, IIZ-DVV).

OIssen, M . (2004) N eoliberalism, globalisation, democracy: challenges for education, G lobalisation, Societies and E ducation, 2(2), 231-276.

Pannu, R. S. (1996) Neoliberal project of globalisation: prospects for democratisation of education, A lberta J ournal of E ducational R esearch, X L 11(2), 87-101.

Quiroz M artin, T. (1997) Women, poverty and adult education in Chile, in: S. Walters (Ed.) G lobalisation, adult education and training. Impact and issues (L ondon, Zed Books).

Richardson, J. (2001) Policy-making in the EU. Interests, ideas and garbage cans of primeval soup, in: J. Richardson (Ed.) European Union. Power and policy making (London, Routledge)

Rikowski, G. (2001) The B attle in Seattle. Its significance for education ( $L$ ondon, T ufnell Press).

Schugurensky, D. (2001) Cinderella and the search for the missing shoe: Latin American adult education policy and practice during the 1990s, J ournal of Education Policy, 16(6), 527-546.

Skager, R. (1978) Lifelong education and evaluation practice (Oxford, Pergamon Press).

Suchodolski, B. (1976) Lifelong education-some philosophical aspects, in: R. H. Dave (Ed.) F oundations of lifelong education ( $O$ xford, Pergamon Press).

T uijnman, A. \& Boström, A. K. (2002) Changing notions of lifelong education and lifelong learning, International R eview of E ducation, 48(1/2), 93-110.

Waddington, S. (2002) Reflecting on policy, in: J. Field (Ed.) Promoting European dimensions in lifelong learning (L eicester, N IACE).

Wain, K . (1982) T he normative foundations of lifelong education, E ducation, 1(1), 7-11.

Wain, K. (1985) Lifelong education and participation. An introduction, in: K. Wain. (Ed.) L ifelong education and participation ( $M$ alta, T he U niversity of $M$ alta Press).

Wain, K. (1987) Philosophy of lifelong education (L ondon, C room H elm).

Wain, K . (2004a) The learning society in a postmodern world (N ew Y ork, Peter L ang).

Wain, K. (2004b) Lifelong learning: some critical reflections, in: D. Caruana \& P. M ayo (Eds) Perspectives on lifelong learning in the M editerranean (Bonn, IIZ-DVV).

Walters, S. (Ed.) (1997) G lobalisation, adult education and training. Impact and issues (L ondon, Zed Books). 
Walters, S., Borg, C., M ayo, P. \& Foley, G. (2004) Economics, politics and adult education, in: G. Foley (Ed.) Dimensions of adult learning. adult education and training in a global era (Sydney, Allen \& U nwin).

Williams, R. (1989) R esources of hope (L ondon, Verso).

Williamson, B. (1998) Lifeworlds and learning. Essays in the theory, philosophy and practice of lifelong learning (L eicester, NIACE). 
Copyright of Globalisation, Societies \& Education is the property of Carfax Publishing Company. The copyright in an individual article may be maintained by the author in certain cases. Content may not be copied or emailed to multiple sites or posted to a listserv without the copyright holder's express written permission. However, users may print, download, or email articles for individual use. 